\title{
Konstytucyjne podstawy szczególnej opieki zdrowotnej nad osobami niepełnosprawnymi - uwagi na tle art. 68 ust. 3 Konstytucji RP
}

\author{
Radosław Mędrzycki \\ Uniwersytet Kardynała Stefana Wyszyńskiego w Warszawie \\ r.medrzycki@uksw.edu.pl \\ ORCID: https://orcid/org/0000-0002-9407-4881 \\ Sebastian Sikorski \\ Uniwersytet Kardynała Stefana Wyszyńskiego w Warszawie \\ s.sikorski@uksw.edu.pl \\ ORCID: https://orcid.org/0000-0002-7974-9537
}

\section{Wstęp}

Szczególnie ważnym społecznie obszarem zainteresowania prawa administracyjnego są kwestie szczególnej opieki zdrowotnej nad osobami niepełnosprawnymi. Waga zagadnienia jest podwójnie kwalifikowana: po pierwsze, chodzi o ważkie kwestie opieki zdrowotnej pozostające racjonalnie związane $\mathrm{z}$ podstawową potrzebą człowieka - bezpieczeństwem, po drugie, idzie o działania inkluzyjne, wyrównawcze, tak silnie powiązane $\mathrm{z}$ motywowanymi aksjologicznie dyrektywami ochrony godności człowieka potrzebującego i solidarności.

Celem artykułu jest próba odniesienia się do konstytucyjnych podstaw szczególnej opieki zdrowotnej nad osobami niepełnosprawnymi. Autorzy, chcąc ukazać realizację tych podstaw, poddali analizie relatywnie niedawno (9 maja $2018 \mathrm{r}$.) uchwaloną ustawę o szczególnych rozwiązaniach wspierających osoby o znacznym stopniu niepełnosprawności (u.s.r.w.n.) ${ }^{1}$. Chodzi zatem o ukazanie stosun- 
kowo nowych rozwiązań prawnych, które w założeniu mają realizować konstytucyjne wartości.

\section{Podstawy aksjologiczne}

Artykuł 68 Konstytucji brzmi: 1) Każdy ma prawo do ochrony zdrowia. 2) Obywatelom, niezależnie od ich sytuacji materialnej, władze publiczne zapewniają równy dostęp do świadczeń opieki zdrowotnej finansowanej ze środków publicznych. Warunki i zakres udzielania świadczeń określa ustawa. 3) Władze publiczne są obowiązane do zapewnienia szczególnej opieki zdrowotnej dzieciom, kobietom ciężarnym, osobom niepełnosprawnym i osobom w podeszłym wieku. 4) Władze publiczne są obowiązane do zwalczania chorób epidemicznych i zapobiegania negatywnym dla zdrowia skutkom degradacji środowiska. 5) Władze publiczne popierają rozwój kultury fizycznej, zwłaszcza wśród dzieci i młodzieży.

Ustawodawca konstytucyjny posłużył się w nim trzema rodzajami określeń: „ochrona zdrowia”, „świadczenia opieki zdrowotnej”, „szczególna opieki zdrowotnej”. W literaturze wskazuje się, iż ochrona zdrowia jest zakresowo najszerszym pojęciem, pojęciem węższym jest zaś opieka zdrowotna, obejmująca nie tylko świadczenia opieki zdrowotnej, lecz również „inne świadczenia powiązane funkcjonalnie ze świadczeniami zdrowotnymi choćby przez fakt ich wykonywania przez podmioty lecznicze lub w podmiotach leczniczych, w tym także świadczenia rzeczowe"2.

Zwornikiem art. 68 jest ustanowienie szerokiego, przysługującego każdemu prawa podmiotowego do ochrony zdrowia (ust. 1) ${ }^{3}$. Zdrowie, podobnie jak i życie, wymieniane są w orzecznictwie i nauce prawa jako wartości podstawowe, których bezpośrednim rdzeniem jest godność człowieka ${ }^{4}$. Naruszenie prawa do ochrony zdrowia, w szczególności pozostawienie osoby bez wymaganej opieki, skutkujące ekskluzją społeczną, stanowi samo przez się łamanie godności człowieka ${ }^{5}$ znajdującej się nie tyle u podstawy, co „wewnątrz” tego prawa - godność stanowi naj-

L. Bosek, Artykuł 68 Konstytucji, [w:] Konstytucja RP. Komentarz do art. 1-86, red. M. Safian, L. Bosek, Warszawa 2016.

$3 \quad$ Wyrok TK z dnia 7 stycznia 2004 r., 14/03. Jest kwestią sporną wśród prawników, czy art. 68 ust. 1 Konstytucji stanowi „zamkniętą całość”, czy też powinien być interpretowany systemowo z dookreślającymi go art. 68 ust. 2 i 3 Konstytucji. Porównaj argumenty na ten temat np. w: J. Trzciński, M. Wiącek, Artykuł 68, [w:] Konstytucja Rzeczpospolitej Polskiej. Komentarz, red. L. Garlicki, M. Zubik, t. 2, wyd. 2, Warszawa 2016; D.E. Lach, Zasada równego dostępu do świadczeń opieki zdrowotnej, Warszawa 2011, s. 31 i n. Por. W. Brzozowski, Konstytucyjne gwarancje ochrony zdrowia, [w:] Pojęcie, źródła i zakres prawa medycznego. System prawa medycznego, red. R. Kubiak, L. Kubicki, t. 1, Warszawa 2018, s. 120-121; A. Surówka, Miejsce konstytucyjnego prawa do ochrony zdrowia w systemie praw $i$ wolności człowieka $i$ obywatela, „Przegląd Prawa Konstytucyjnego” 2012, nr 3, s. 98-99. nych ze środków publicznych, [w:] E. Nojszewska, W. Malinowski, S. Sikorski, Komercyjne świadczenia usług publicznych przez szpitale publiczne, Warszawa 2017, s. 79 i przywołane tam orzecznictwo, s. 84. 
Konstytucyjne podstawy szczególnej opieki zdrowotnej nad osobami niepełnosprawnymi...

głębszą rację obrony tego prawa ${ }^{6}$. Następuje swoiste sprzężenie zwrotne między lepszym zdrowiem, związanym $\mathrm{z}$ dostępem osób niepełnosprawnych do ochrony zdrowia, a osiągnięciami w takich sferach, jak edukacja, zatrudnienie, rodzina, społeczeństwo czy życie publiczne ${ }^{7}$. Prawo do ochrony zdrowia ma być także równe dla każdego obywatela (art. 68 ust. 2 Konstytucji). Widzimy tu specyficzne uszczegółowienie: o ile prawo podmiotowe do ochrony zdrowia przysługuje każdemu, o tyle równość dostępu do opieki zdrowotnej finansowanej ze środków publicznych stanowi aksjologiczną podstawę w odniesieniu już tylko do obywatela. Zakłada to także przyzwolenie na częściową prywatyzację względem całości ochrony zdrowia. Jak stwierdza Trybunał Konstytucyjny, chodzi o równość dostępu niezależną od sytuacji materialnej obywatela. Proklamowana równość stanowi rozwinięcie konstytucyjnej zasady równości wyrażonej w art. 32 Konstytucji, jak i koncepcji solidaryzmu społecznego. „Zasady korzystania ze świadczeń opieki zdrowotnej w tym zakresie są bowiem niezależne od zakresu partycypacji poszczególnych członków wspólnoty obywatelskiej w tworzeniu zasobu środków publicznych stanowiących źródło ich finansowania. Podobnie też jak sam dostęp do świadczeń, musi to być równość w ujęciu rzeczywistym, a nie tylko formalnym"8. Podstawą tego typu działalności jest solidarność społeczna, a także zasada wyrównywania niezawinionych krzywd i upośledzeń ${ }^{9}$.

Jak wskazuje się w orzecznictwie TK, ustawodawca ma prawo do takiego unormowania dostępności do świadczeń, aby część z nich była w całości lub części odpłatna. Jednakże naszym zdaniem byłoby naruszeniem godności człowieka oraz naruszało prawo do ochrony zdrowia stworzenie systemu w pełni odpłatnego albo też tak odpłatnego, iż poza grupą tą znalazłaby się świadczenia, których „celem jest usunięcie bezpośredniego zagrożenia życia człowieka oraz zapobieżenie kalectwu lub innego rodzaju trwałym i ciężkim uszczerbkom na zdrowiu" ${ }^{10}$. Problematyczne pozostaje jednak postawienie granicy - gdzie już jest, a gdzie jeszcze nie naruszona godność człowieka czy jego prawo do ochrony zdrowia w związku z systemem kształtowanym na wzór „prawa spektaklu”"1. O ile słusznie podkreśla się w literaturze, że prawo do ochrony zdrowia nie oznacza prawa do bycia wyleczonym ${ }^{12}$, to jednak trudno nie stwierdzić, iż należy dążyć do ustanowienia takiego systemu

6 M. Granat, Godność człowieka a problem bezdomności, [w:] Bezdomność - problemy prawne, innowacyjne rozwiązania, red. I. Lipowicz, Warszawa 2016, s. 20.

$7 \quad$ E. Księżopolska-Orłowska, A. Wilmowska-Pietruszyńska, Opieka zdrowotna dla osób z niepełnosprawnościami, [w:] Rehabilitacja - wsparcie - inkluzja: w kierunku polityki wobec niepełnosprawności, red. M. Anasza, J. Wojtyńska, H. Drachal, Warszawa 2016, s. 57.

$8 \quad$ Wyrok TK z dnia 7 stycznia 2004 r., 14/03.

9 G. Szklarski, Konstytucyjne prawa socjalne na tle zasady sprawiedliwości społecznej, „Przegląd Prawa Publicznego" 2014, nr 3, s. 63.

10 J. Trzciński, M. Wiącek, Artykuł $68 \ldots$

11 I. Lipowicz, Dobro wspólne, „Ruch Prawniczy, Ekonomiczny i Socjologiczny” 2017, nr 3, s. 28.

12 Por. W. Brzozowski, Konstytucyjne gwarancje..., s. 122 i cytowana tam literatura. 
opieki zdrowotnej, który najpełniej realizować będzie ten właśnie cel lub - jeżeli ad casum to niemożliwe (np. osoby z niepełnosprawnościami) - cel ograniczenia cierpień i zmniejszenie niedogodności ${ }^{13}$. Ekonomia i mgliste deklaracje o konieczności alokacji środków finansowych w inne obszary państwa socjalnego nie mogą stać się prostym wytłumaczeniem ciągłego niedofinansowania ochrony zdrowia.

W końcu ustawodawca konstytucyjny wyróżnia określone kategorie podmiotów, którym ustawodawca zwykły winien zapewnić szczególną opiekę zdrowotną (art. 68 ust. 3 Konstytucji). Są to: dzieci, kobiety ciężarne, osoby niepełnosprawne oraz osoby w podeszłym wieku. Zrozumienie podstaw aksjologicznych tego rozwiązania powinno odbyć się poprzez zrozumienie wspólnych cech charakteryzujących wymienione grupy osób. Jak stwierdził TK w wyroku z 22 lipca 2008 r., „Wspólną cechą tych podmiotów jest to, że z jednej strony najczęściej mają one zwiększone zapotrzebowanie na świadczenia opieki zdrowotnej, z drugiej - są w stopniu mniejszym niż przeciętny samodzielne. Toteż należy podzielić wyrażany w literaturze pogląd, że zakres podmiotowy art. 68 ust. 3 Konstytucji uwarunkowany jest względami humanitarnymi oraz troską o zapewnienie rozwoju Narodu"14. Poddanie szczególnej opiece zdrowotnej określonej kategorii osób wynika zatem z konieczności „Zwiększonego zapotrzebowania” na świadczenia opieki zdrowotnej ${ }^{15}$.

\section{Pojęcie równego dostępu do świadczeń opieki zdrowotnej finansowanej ze środków publicznych}

Jak już wskazano, ustrojodawca nałożył na ustawodawcę zwykłego obowiązek wypracowania szczegółowej koncepcji normatywnej opieki zdrowotnej, przy zachowaniu równości tej opieki. Sam bowiem ustrojodawca "nie przesądził o konstrukcji tego systemu jako całości ani jego poszczególnych elementów charakteru prawnego źródeł finansowania świadczeń zdrowotnych, charakteru i struktury płatnika (płatników) tych świadczeń czy też struktury własnościowej świadczeniodawców. Pewne ograniczenia swobody ustawodawcy w tym zakresie mogą jednak wynikać $\mathrm{z}$ innych konstytucyjnych zasad lub wartości. Z obowiązku rzeczywistego zapewnienia przez władze publiczne warunków realizacji prawa do ochrony zdrowia, które nie może być traktowane jako uprawnienie iluzoryczne bądź czysto potencjalne, wynika jednak wymaganie, iż system ten - jako całość - musi być efektywny"16. Na podstawie orzecznictwa TK i literatury można wskazać podstawowe cechy normatywnego modelu opieki zdrowotnej, finansowanego ze świadczeń publicznych. Są to dyrektywy:

13

14 Wyrok TK z dnia 22 lipca 2008 r., K 24/07.

15 J. Trzciński, M. Wiącek, Artykuł 68...

16 Por. W. Brzozowski, Konstytucyjne gwarancje..., s. 124. 
- realizacji tego modelu przez władze publiczne z wykorzystaniem środków publicznych (organy państwa, ale także, co ważne, organy samorządu terytorialnego $)^{17}$;

- ustawowej określoności świadczeń medycznych przysługujących beneficjentom;

- braku konieczności, aby oferowane świadczenia zdrowotne uwzględniały najnowsze osiągnięcia wiedzy medycznej, jednak z dbałością, aby świadczenia odpowiadały na zapotrzebowanie beneficjentów ${ }^{18}$;

- równości dostępu z dyskryminacją pozytywną określonych podmiotów ${ }^{19}$.

Podsumowując, należy zgodzić się z TK, że „wyraźna jest jedynie wola ustrojodawcy niedopuszczenia do wykreowania całkowicie rynkowego systemu ochrony zdrowia (tzw. samofinansowanie). W pozostałym zakresie ustawodawca zwykły, realizując własne cele polityczne i społeczne, może swobodnie kształtować określony model ochrony zdrowia. Konieczne jest jednak uwzględnienie dyrektyw wynikających z rozpatrywanych łącznie norm art. 68 ust. 1 i 2 Konstytucji: system ochrony zdrowia jako całość musi gwarantować realizację prawa do ochrony zdrowia poszczególnych jednostek, zaś stanowiące jego komponent świadczenia finansowane ze środków publicznych muszą być dostępne dla wszystkich obywateli na zasadzie równości" ${ }^{20}$.

\section{Pojęcie szczególnej opieki zdrowotnej dla wybranych grup pacjentów i przykłady jej realizacji}

W literaturze wskazuje się, że potrzeba szczególnej opieki wybranych grup pacjentów pozostaje dopełnieniem innych regulacji konstytucyjnych - art. 72 Konstytucji (obowiązku szczególnej ochrony dzieci), art. 69 Konstytucji (obowiązku pomocy osobom niepełnosprawnym), art. 18 i 71 ust. 2 (obowiązku ochrony macierzyństwa i rodzicielstwa) ${ }^{21}$ - ale i one dopełniają art. 68 ust. 3 w ten sposób, iż tworzą podstawy rozumienia poszczególnych grup społecznych w nim wymienionych ${ }^{22}$.

Rozumiejąc aksjologiczną podstawę komentowanej regulacji, należy zastanowić się, co oznacza szczególna opieka zdrowotna. Jej konkretne przejawy będą opisane dalej, tu zostaną wskazane jedynie ogólne założenia, na które zwraca się uwagę w doktrynie. Można odnieść je z jednej strony do wszystkich uprzywilejowanych

17 Wyrok TK z dnia 12 października 2004 r., K 31/02.

18 Wyrok TK $z$ dnia 12 kwietnia 2006 r., Kp 2/04.

19 Patrz np. D.E. Lach, Zasada równego dostępu do świadczeń opieki zdrowotnej, Warszawa 2011, s. 38 i n.; B. Sygit, D. Wąsik, Prawo ochrony zdrowia, Warszawa 2016, s. 16-17.

20 Wyrok TK z dnia 7 stycznia 2004 r., 14/03.

21 J. Trzciński, M. Wiącek, Artykuł 68...

22 L. Bosek, Artykut 68... 
grup społecznych z art. 68 ust. 3 Konstytucji bądź wskazać poszczególne założenia uprzywilejowania każdej grupy $\mathrm{z}$ osobna. W literaturze rozważania podążają w kierunku traktowania wszystkich grup społecznych jako zbiorczej kategorii, której przysługuje szczególna opieka zdrowotna.

W literaturze wskazuje się zatem na potrzebę „troskliwszej opieki”, „opieki częstszej i bardziej szczegółowej"23. Ukazuje się także konieczność stworzenia ustawowych regulacji określonych "uprawnień i przywilejów” dla wskazanych grup odbiorców, ale także "ponadstandardowych obowiązków dla władzy publicznej, a pośrednio także dla podmiotów leczniczych"24. Dalej Leszek Bosek podkreśla, że „szczególna” opieka zdrowotna „powinna pełniej realizować interesy zdrowotne uprawnionych niż w przypadku pozostałych grup uprawnionych". Z kolei według Bogusława Banaszaka szczególność opieki zdrowotnej oznacza „konieczność zapewnienia opieki zorganizowanej na innych zasadach niż w przypadku opieki powszechnej. Chodzi tu zwłaszcza o obowiązek tworzenia i finansowania specjalnych poradni lub szczególnych warunków korzystania z poradni powszechnych dla grup (kategorii) wymienionych $\mathrm{w}$ art. 68 ust. 3, a także stworzenie dla nich szczególnych świadczeń (urlopy, zasiłki)"25. Do szczególnej opieki wybranych grup społecznych odniósł się także Trybunał Konstytucyjny w kontekście możliwości tymczasowego aresztowania kobiet w ciąży. Zdaniem TK pojęcie szczególnej opieki zdrowotnej należy rozumieć, po pierwsze, jako wykraczające „poza sferę zwykłej, powszechnej opieki zdrowotnej, powinna więc być [ona - dopisek własny] wzmożona, intensywniejsza lub bardziej wyspecjalizowana, czyli dostosowana do specyfiki potrzeb charakterystycznych dla danej grupy podmiotów”, po drugie, „celem opieki zdrowotnej jest nie tylko leczenie i rehabilitacja, ale również dbałość o zachowanie zdrowia oraz zapobieganie chorobom”, po trzecie, „»szczególność« dotyczyć może (łącznie albo rozłącznie): warunków, zakresu, dostępu lub finansowania tych świadczeń" ${ }^{26}$.

$\mathrm{Z}$ punktu widzenia omawianej problematyki zasadna jest analiza najnowszych zmian legislacyjnych realizujących wskazany powyżej obowiązek określony na gruncie przepisu art. 68 ust. 3 Konstytucji, jakim jest szczególna systemowa opieka nad osobami niepełnosprawnymi, a mianowicie ustawę $z$ dnia 9 maja 2018 r. o szczególnych rozwiązaniach wspierających osoby o znacznym stopniu niepełnosprawności (u.s.r.w.n.). Jak wskazują sami projektodawcy, osoby niepełnosprawne powinny być objęte szczególną opieką ze strony państwa. Konkretyzując ten obowiązek, wprowadza się rozwiązania, których celem ,jest określenie szczególnych uprawnień w dostępie do świadczeń opieki zdrowotnej, usług farmaceu-

23 G. Szklarski, Konstytucyjne prawa..., s. 64.

24 L. Bosek, Artykut 68...

25 B. Banaszak, Artykuł 68, [w:] Konstytucja Rzeczpospolitej Polskiej. Komentarz, red. B. Banaszak, wyd. 2, Warszawa 2012.

26 Wyrok TK z 22 lipca 2008 r, sygn. akt K 24/07. 
Konstytucyjne podstawy szczególnej opieki zdrowotnej nad osobami niepełnosprawnymi...

tycznych oraz wyrobów medycznych osób posiadających orzeczenie o znacznym stopniu niepełnosprawności"27. Biorąc to pod uwagę, należy rozważyć zakres wprowadzonych zmian w ujęciu katalogu osób uprawnionych oraz zakresu uprawnień z odniesieniem się do dotychczas obowiązujących w tym zakresie rozwiązań.

Zgodnie z art. 1 u.s.r.w.n. określa się szczególne uprawnienia świadczeniobiorców posiadających orzeczenie o znacznym stopniu niepełnosprawności w zakresie dostępu do świadczeń opieki zdrowotnej ${ }^{28}$, z zastrzeżeniem zawartym w przepisie art. 2 u.s.r.w.n., że osoby te są jednocześnie zliczane do świadczeniobiorców oraz osób uprawnionych do świadczeń opieki zdrowotnej na podstawie przepisów o koordynacji w rozumieniu przepisów ustawy z dnia 27 sierpnia 2004 r. o świadczeniach opieki zdrowotnej finansowanych ze środków publicznych (u.ś.o.z) ${ }^{29}$. Nie nastręcza trudności zdefiniowanie tak wskazanych świadczeniobiorców. Przepis art. 3 u.ś.o.z. określa bowiem warunki uzyskania statusu ubezpieczonego. Są to w szczególności warunki dotyczące miejsca zamieszkania, obywatelstwa czy też dokumentu uprawniającego cudzoziemca do pobytu w Polsce. Osoba spełniająca te warunki może uzyskać ubezpieczenie zdrowotne jako osoba objęta obowiązkowym lub dobrowolnym ubezpieczeniem zdrowotnym bądź jako członek rodziny takiej osoby ${ }^{30}$. Pewne trudności pojawiają się przy definiowaniu osoby o znacznym stopniu niepełnosprawności; w doktrynie oceniono negatywnie także inne definicje stopni niepełnosprawności ${ }^{31}$. Analizowana regulacja nie zawiera definicji ustawowej tej grupy osób. Natomiast zgodnie z art. 2 pkt 10 ustawy o rehabilitacji zawodowej i społecznej oraz zatrudnianiu osób niepełnosprawnych (u.r.z.o.n.) ${ }^{32}$ przez niepełnosprawność należy rozumieć „trwałą lub okresową niezdolność do wypełniania ról społecznych $\mathrm{z}$ powodu stałego lub długotrwałego naruszenia sprawności organizmu, w szczególności powodującą niezdolność do pracy”. Jednocześnie zgodnie z przepisem art. 3 u.r.z.o.n. niepełnosprawność określa się w ramach trzech stopni, w tym stopnia kwalifikującego osoby do skorzystania z ustawy o szczególnym wsparciu, tj. znacznego stopnia niepełnosprawności. Do tej kategorii zaliczane są osoby z naruszoną sprawnością organizmu, niezdolne do pracy albo zdolne do pracy jedynie w warunkach pracy chronionej i wymagające w celu pełnienia ról społecznych stałej lub długotrwałej opieki i pomocy innych osób w związku z nie-

27 Druk nr 2479. Poselski projekt ustawy o szczególnych rozwiązaniach wspierających osoby o znacznym stopniu niepełnosprawności.

28 Poza katalogiem osób uprawnionych znalazły się więc osoby nieposiadające stosownego orzeczenia oraz osoby z umiarkowanym i lekkim stopniem niepełnosprawności.

29 Dz.U. z 2017 r. poz. 1938 z późn. zm.

30 Ustawa o świadczeniach opieki zdrowotnej finansowanych ze środków publicznych. Komentarz, wyd. 3, red. A. Pietraszewska-Macheta, WKP/el. 2018.

31 Szerzej: K. Kurowski, Wolności i prawa człowieka i obywatela z perspektywy osób z niepełnosprawnościami, Biuro Rzecznika Praw Obywatelskich, Warszawa 2014, s. 22 i n.

32 Ustawa z dnia 27 sierpnia 1997 r. o rehabilitacji zawodowej i społecznej oraz zatrudnianiu osób niepełnosprawnych (Dz.U. z 2018 r. poz. 511). 
zdolnością do samodzielnej egzystencji (art. 4 ust. 1 u.r.z.o.n). Odrębnie w przepisie art. 4a u.r.z.o.n. zdefiniowano jednak niepełnosprawność osób poniżej 16. roku życia, przyjmując, że mają status osoby niepełnosprawnej, o ile mają naruszoną sprawność fizyczną lub psychiczną o przewidywanym okresie trwania powyżej 12 miesięcy z powodu wady wrodzonej, długotrwałej choroby lub uszkodzenia organizmu, powodującą konieczność zapewnienia im całkowitej opieki lub pomocy w zaspokajaniu podstawowych potrzeb życiowych w sposób przewyższający wsparcie potrzebne osobie $\mathrm{w}$ danym wieku ${ }^{33}$. Jednocześnie zgodnie $\mathrm{z}$ ust. 2 tego przepisu (u.r.z.s.n.) odmiennie uregulowano sposób oceny ich niepełnosprawności, bez stopniowania niepełnosprawności, którą stosuje w przypadku osób powyżej 16. roku życia ${ }^{34}$. Powstał więc problem możliwości skorzystania z uprawnień, jakie daje nowa regulacja właśnie dla osób poniżej 16. roku życia. Zadaniem Daniela E. Lacha zawężenie w tej ustawie kręgu jej beneficjentów do osób „posiadających orzeczenie o znacznym stopniu niepełnosprawności” spowodowało, że nie dotyczy ona niepełnosprawnych dzieci i młodzieży do ukończenia 16 . roku życia ${ }^{35}$. Miało to wpływ na dwukrotną nowelizację u.ś.o.z. Pierwsza $z$ nich polegała na zmianie brzmienia przepisu art. 47c ust. 1 i dodała do grona wyżej wymienionych osób uprawnionych również drugą grupę świadczeniobiorców do 18. roku życia, posiadających orzeczenie o niepełnosprawności, łącznie ze wskazaniami konieczności stałej lub długotrwałej opieki lub pomocy innej osoby w związku ze znacznie ograniczoną możliwością samodzielnej egzystencji oraz konieczności stałego współudziału na co dzień opiekuna dziecka w procesie jego leczenia, rehabilitacji i edukacji.

Druga natomiast, zmieniając brzmienie przepisu art. 47 ust. 1a, określiła prawo świadczeniobiorców do 18. roku życia do uprzywilejowanego dostępu do wyrobów medycznych (określonych w przepisach wydanych na podstawie art. 38 ust. 4

Jak słusznie zauważa Mirosław Włodarczyk, ustawodawca niekonsekwentnie posługuje się pojęciem naruszonej sprawności organizmu. W przypadku osób, które nie ukończyły 16. roku życia, mowa jest zaledwie o dwóch aspektach tej sprawności: psychicznym lub fizycznym. Nasuwać się może wątpliwość powstająca na tle wykładni gramatycznej tego przepisu co do użycia alternatywy łącznej „lub”, ponieważ sprawność organizmu może być naruszona wyłącznie w sferze fizycznej, wyłącznie w sferze psychicznej, jak również w obu tych sferach jednocześnie. Drugą przesłanką jest konieczność zapewnienia opieki lub pomocy innej osoby w zaspokajaniu podstawowych potrzeb życiowych w sposób przewyższający wsparcie potrzebne osobie w danym wieku. Pojęcie opieki, jak również pojęcie pomocy nie zostały zdefiniowane w komentowanej ustawie ani w rozporządzeniu w sprawie kryteriów oceny niepełnosprawności u osób w wieku do 16. roku życia. Zdaniem tego autora na uwagę zasługuje okoliczność, że w stosunku do osoby niepełnosprawnej istnieć może wyłącznie konieczność opieki, wyłącznie konieczność pomocy albo konieczność zapewnienia tych czynności łącznie. Ustawodawca używa w przypadku opieki lub pomocy określenia „całkowita” (art. 4a u.r.z.s.n.), podczas gdy w rozporządzeniu wykonawczym posługuje się określeniem „stała” opieka lub pomoc (§ 2 rozporządzenia Ministra Pracy i Polityki Społecznej z dnia 1 lutego 2002 r. w sprawie kryteriów oceny niepełnosprawności u osób w wieku do 16. roku życia (Dz.U. z 2002 r. Nr 17, poz. 162 z późn. zm.); dalej: r.k.o.n.); szerzej: Ustawa o rehabilitacji zawodowej i społecznej oraz zatrudnianiu osób niepełnosprawnych. Komentarz, red. M. Włodarczyk, WK/el. 2015.

$34 \quad K r y t e r i a$ oceny niepełnosprawności osób w wieku do 1. roku życia reguluje r.k.o.n.

35 D.E. Lach, Kilka uwag o nowych instrumentach wsparcia dla osób niepełnosprawnych, „Praca i Zabezpieczenie Społeczne" 2018, nr 12, s. 2-9. 
Konstytucyjne podstawy szczególnej opieki zdrowotnej nad osobami niepełnosprawnymi...

ustawy o refundacji) bez uwzględnienia okresów użytkowania. Oczywiście zgodnie $\mathrm{z}$ tym przepisem o ilości miesięcznego zaopatrzenia w te wyroby decyduje każdorazowo osoba uprawniona do wystawienia zlecenia. Zasady określania o niepełnosprawności lub jej stopnia osób niepełnoletnich ${ }^{36}$ podaje wydane na podstawie art. 6c ust. 9 u.r.z.o.n. rozporządzenie Ministra Gospodarki, Pracy i Polityki Społecznej w sprawie orzekania o niepełnosprawności i stopniu niepełnosprawności ${ }^{37}$. Zgodnie z przepisem $\$ 2$ i 3 tego rozporządzenia orzeczenia w tym zakresie wydają powiatowe zespoły do spraw orzekania o niepełnosprawności oraz wojewódzkie zespoły do spraw orzekania o niepełnosprawności. Orzeczenie wydawane jest na wniosek osoby zainteresowanej, jej przedstawiciela ustawowego lub, za ich zgodą, na wniosek ośrodka pomocy społecznej. Oprócz ustalenia niepełnosprawności lub stopnia niepełnosprawności w orzeczeniu tym powinny zawarte być również wskazania dotyczące konieczności stałej lub długotrwałej opieki lub pomocy innej osoby w związku ze znacznie ograniczoną możliwością samodzielnej egzystencji oraz konieczności stałego współudziału na co dzień opiekuna dziecka w procesie jego leczenia, rehabilitacji i edukacji. Te dwie przesłanki mają kluczowe znaczenie dla osób niepełnoletnich chcących skorzystać z nowo przyznanych uprawnień osobom niepełnosprawnym ${ }^{38}$. Nasuwa się tu jednak pewna wątpliwość. Jak zasadnie wskazuje Magdalena Paluszkiewicz, powoduje to konieczność stałej lub długotrwałej opieki bądź pomocy innej osoby w związku ze znacznie ograniczoną możliwością samodzielnej egzystencji. Jednak występuje tu pewna niekonsekwencj, ponieważ pojęcie stałej lub długotrwałej opieki lub pomocy innej osoby stanowi element warunkujący zaliczenie do znacznego stopnia niepełnosprawności, podczas gdy w analizowanym przepisie stanowi o ograniczonej możliwości samodzielnej egzystencji. Natomiast przepis art. 4 ust. 1 u.r.z.s.n. posługuje się terminem „niezdolność do samodzielnej egzystencji”, który został zdefiniowany w ust. 4 tego przepisu. W konsekwencji usprawiedliwiony jest wniosek, że ograniczona możliwość samodzielnej egzystencji powinna być rozumiana inaczej aniżeli niezdolność do samo-

36 Jak podkreśla D.E. Lach, NFZ jest uprawniony do ustalenia stopnia niepełnosprawności osoby uprawnionej do świadczeń opieki zdrowotnej na podstawie przepisów o koordynacji poprzez zwrócenie się do Zakładu Ubezpieczeń Społecznych o przeprowadzenie stosownego badania lekarskiego lub o dokonanie oceny, czy zagraniczne orzeczenie o niepełnosprawności (jej stopniu) można uznać za tożsame z polskim orzeczeniem o znacznym stopniu niepełnosprawności. Jednak wobec braku koordynacji systemów orzeczniczych oraz zróżnicowanego w poszczególnych państwach członkowskich UE stopniowania niepełnosprawności należy przyjąć, że znaczny stopień niepełnosprawności w rozumieniu polskich przepisów będzie musiał być ustalony (na podstawie badania i/lub analizy dokumentów) w odniesieniu do każdej osoby uprawnionej do świadczeń opieki zdrowotnej na podstawie przepisów o koordynacji, chcącej skorzystać z przywilejów wprowadzonych przepisami ustawy o szczególnych rozwiązaniach wspierających osoby o znacznym stopniu niepełnosprawności; szerzej: D.E. Lach, Kilka uwag..., s. 2-9.

37 Rozporządzenie Ministra Gospodarki, Pracy i Polityki Społecznej z dnia 15 lipca 2003 r. w sprawie orzekania o niepełnosprawności i stopniu niepełnosprawności (tekst jedn. Dz.U. z 2018 r. poz. 2027).

38 K. Urban, E. Warmińska, Nowe uprawnienia pacjentów niepełnosprawnych w systemie ochrony zdrowia w szczególności w zakresie rehabilitacji, LEX/el. 2018. 
dzielnej egzystencji ${ }^{39}$, co ma znaczenie dla ewentualnych szczególnych uprawnień danej osoby.

Przechodząc do zakresu przedmiotowego ustawy z dnia 9 maja 2018 r. o szczególnych rozwiązaniach wspierających osoby o znacznym stopniu niepełnosprawności (Dz.U. z 2018 r. poz. 932), należy wskazać, że zgodnie z przepisem art. 3 ust. 1 i 2 tej ustawy wsparcie obejmuje zapewnienie dostępności świadczeń opieki zdrowotnej odpowiednich dla świadczeniobiorców, w tym wskazanej powyżej kategorii osób niepełnosprawnych. Jak zasadnie podnosi D.E. Lach, posłużenie się przez ustawodawcę w treści powyższego przepisu określeniem „wsparcie” wskazuje na zapewnienie dostępności świadczeń opieki zdrowotnej odpowiednich dla wskazanych grup świadczeniobiorców prawo do korzystania poza kolejnością ze wszelkich świadczeń opieki zdrowotnej oraz usług farmaceutycznych udzielanych w aptekach, wykraczający poza tak wyznaczony zakres wsparcia ${ }^{40}$. Konieczne jest zatem wyjaśnienie zakresu uprawnień, jakie ustawodawca na podstawie tej regulacji przyznał określonej powyżej grupie osób niepełnosprawnych. Wskaże to, w jaki sposób ustawodawca realizuje konstytucyjny nakaz szczególnej opieki osób niepełnosprawnych. Jednocześnie należy poczynić generalną uwagę, że będąca przedmiotem analizy ustawa nie wprowadza nowych uprawnień, a jedynie dodaje określone osoby niepełnosprawne do grupy osób (na przykład inwalidów wojennych) posiadających już analogiczne uprawnienia. Uprawnienia te sprowadzają się do zapewnienia lepszego dostępu do wyrobów medycznych, świadczeń zdrowotnych (w tym ambulatoryjnych świadczeń specjalistycznych) oraz usług farmaceutycznych udzielanych w aptekach.

Pierwsze ze wskazanych uprawnień sprowadza się do zniesienia okresów użytkowania wyrobów medycznych, jednak bez zmiany samej zasady refundacji, czyli limitu finansowania przez NFZ oraz wysokości dopłaty pacjenta. Ponadto uprawnienie to dotyczy tylko wyrobów medycznych wydawanych na zlecenie. W praktyce oznacza to, że zgodnie z przepisem art. 47 ust. 1 ustawy o świadczeniach opieki zdrowotnej (u.ś.o.z.) decyzja terapeutyczna, a w konsekwencji ilość zaopatrzenia w te wyroby określana jest każdorazowo przez osobę uprawnioną do wystawienia zlecenia, o której mowa w art. 2 pkt 14 ustawy o refundacji leków, środków spożywczych specjalnego przeznaczenia żywieniowego oraz wyrobów medycznych ${ }^{41}$. Celem jest więc zwiększenie dostępności ilościowej wyrobów medycznych dla tych

39 M. Paluszkiewicz, [w:] Ustawa o rehabilitacji zawodowej i społecznej oraz zatrudnianiu osób niepełnosprawnych. Komentarz, red. M. Włodarczyk, WK/el. 2015.

40 D.E. Lach, Kilka uwag..., s. 2-9.

41 Ustawa z dnia 12 maja 2011 r. o refundacji leków, środków spożywczych specjalnego przeznaczenia żywieniowego oraz wyrobów medycznych (Dz.U. z 2017 r. poz.1844 z późn. zm.). 
Konstytucyjne podstawy szczególnej opieki zdrowotnej nad osobami niepełnosprawnymi...

osób, które z uwagi na swój stan kliniczny potrzebują większej ilości wyrobów medycznych niż określone limitami ${ }^{42}$.

Polepszenie dostępu do świadczeń zdrowotnych oraz usług farmaceutycznych udzielanych w aptece polega na przyznaniu zgodnie z przepisem art. 47c ust. 2 u.o.ś.z. wskazanym osobom niepełnosprawnym dostępu do świadczeń zdrowotnych, objętych tzw. koszykiem świadczeń gwarantowanych, prawa uzyskania poza kolejnością, tj. poza listą oczekujących, sporządzaną przez świadczeniodawców zgodnie z przepisem art. 20 ust. 2 u.ś.o.z.

Zgodnie z przywołanym przepisem art. 47c ust. 3 i 4 u.o.ś.z. świadczenie zdrowotne dla tej kategorii osób powinno być udzielone już w dniu zgłoszenia, a jeśli nie jest to możliwe, wówczas świadczeniodawca zobowiązany jest do wyznaczenia innego terminu poza kolejnością, lecz nie dłuższego niż 7 dni roboczych od dnia zgłoszenia.

Przepis art. 47c ust. 1 u.ś.o.z. określa enumeratywnie krąg osób uprawnionych do korzystania ze świadczeń opieki zdrowotnej oraz usług farmaceutycznych udzielanych w aptekach poza kolejnością. Przepis ten w ust. 5 determinuje również sposób obsługi tej grupy pacjentów, polegający na zamieszczeniu stosownej informacji przez świadczeniodawców oraz kierowników aptek. Szczególnym przyznanym uprawnieniem jest również prawo do świadczeń specjalistycznych bez skierowania, zgodnie z dyspozycją przepisu art. 57 u.ś.o.z. Dotyczy to jednak wyłącznie świadczeń specjalistycznych w ramach opieki ambulatoryjnej, na co wskazuje gramatyczne brzmienie tego przepisu. Zmianie uległy również zasady finansowania świadczeń takich jak rehabilitacja lecznicza. Zgodnie z obecnym brzmieniem przepisu art. 136 ust. 2 u.ś.o.z. pkt la wprowadzono te świadczenia (obok m.in. świadczeń udzielanych w ramach diagnostyki i leczenia onkologicznego) do grupy świadczeń, na które zniesione zostały limity finansowania.

\section{Zakończenie i wnioski}

W odniesieniu do przedstawionych regulacji nasuwa się kilka wniosków. Samo wprowadzenie tych rozwiązań należy oczywiście ocenić jednoznacznie pozytywnie, jednak trzeba zwrócić uwagę, że nastąpiło to relatywnie późno w stosunku do innych osób uprawnionych. Jednocześnie zastrzeżenia może budzić fakt nieobjęcia osób niepełnosprawnych uprzywilejowanym (poza kolejnością) dostępem do świadczeń takich jak rehabilitacja lecznicza, które niejako ex definitione wpisują się w kategorię szczególnie potrzebnych właśnie osobom niepełnosprawnym. Ponadto wątpliwości budzi sam sposób wprowadzenia tych upraw-

K. Urban, E. Warmińska, Nowe uprawnienia... 
nień. Nasuwa się bowiem wniosek, że nie była tu potrzebna ustawa szczególna wprowadzająca te zmiany. Wystarczające było bowiem dodanie tych uprawnień do kluczowej w tym zakresie regulacji, w szczególności do u.ś.o.z. Ponadto fakt, że tak niewielka objętościowo ustawa (ledwie pięć artykułów), zmieniająca tylko poprzez proste dodanie kolejnej grupy osób uprawnionych, wymagała w krótkim okresie zmian w regulacjach powiązanych w zakresie dotyczącym niepełnoletnich osób niepełnosprawnych, którzy pierwotnie zostali całkowicie pominięci, budzi uzasadnione wątpliwości.

Dostrzegając zatem, że analizowana regulacja spełnia założenia szczególnej opieki zdrowotnej nad osobami niepełnosprawnymi, nie można nie zwrócić uwagi na sposób jej wprowadzenia. Prawo administracyjne jest stanowione w celu realizacji określonych wartości. Prawo, urzeczywistniając i chroniąc wartości cenne dla dobra wspólnego, staje się swoistą wartością, o jaką należy dbać. Stąd ważne są w doktrynie głosy podkreślające konieczność zapewnienia odpowiednio wysokiego poziom prawa administracyjnego, jego przejrzystość i komunikatywność ${ }^{43}$.

\section{Akty prawne}

Konstytucja Rzeczypospolitej Polskiej z dnia 2 kwietnia 1997 r. (Dz.U. z 1997 r. Nr 78, poz. 483 ).

Ustawa z dnia 27 sierpnia 1997 r. o rehabilitacji zawodowej i społecznej oraz zatrudnianiu osób niepełnosprawnych (t.j. Dz.U. z 2020 r. poz. 426 z późn. zm.).

Ustawa z dnia 27 sierpnia 2004 r. o świadczeniach opieki zdrowotnej finansowanych ze środków publicznych (t.j. Dz.U. z 2020 r. poz. 1398 z późn. zm.).

Ustawa z dnia 12 maja 2011 r. o refundacji leków, środków spożywczych specjalnego przeznaczenia żywieniowego oraz wyrobów medycznych (Dz.U. z 2020 r. poz. 357 z późn. zm.).

Ustawa z dnia 9 maja 2018 r. o szczególnych rozwiązaniach wspierających osoby o znacznym stopniu niepełnosprawności (Dz.U. z 2018 r. poz. 932).

Rozporządzenie Ministra Pracy i Polityki Społecznej z dnia 1 lutego 2002 r. w sprawie kryteriów oceny niepełnosprawności u osób w wieku do 16 roku życia (Dz.U. z 2002 r. Nr 17, poz. 162).

Rozporządzenie Ministra Gospodarki, Pracy i Polityki Społecznej z dnia 15 lipca 2003 r. w sprawie orzekania o niepełnosprawności i stopniu niepełnosprawności (tekst jedn. Dz.U. z 2018 r. poz. 2027). 
Konstytucyjne podstawy szczególnej opieki zdrowotnej nad osobami niepełnosprawnymi...

\section{Orzecznictwo}

Wyrok TK z dnia 7 stycznia 2004 r., sygn. akt K 14/03.

Wyrok TK z dnia 12 października 2004 r., sygn. akt K 31/02.

Wyrok TK z dnia 12 kwietnia 2006 r., sygn. akt Kp 2/04.

Wyrok TK z dnia 22 lipca 2008 r, sygn. akt K 24/07.

\section{Literatura}

Banaszak B., Artykut 68, [w:] Konstytucja Rzeczpospolitej Polskiej. Komentarz, red. B. Banaszak, wyd. 2, Warszawa 2012.

Bosek L., Artykut 68 Konstytucji, [w:] Konstytucja RP. Komentarz do art. 1-86, red. M. Safian, L. Bosek, Warszawa 2016.

Brzozowski W., Konstytucyjne gwarancje ochrony zdrowia, [w:] Pojęcie, źródła i zakres prawa medycznego. System prawa medycznego, t. 1, red. R. Kubiak, L. Kubicki, Warszawa 2018.

Granat M., Godność człowieka a problem bezdomności, [w:] Bezdomność - problemy prawne, innowacyjne rozwiązania, red. I. Lipowicz, Warszawa 2016.

Księżopolska-Orłowska E., Wilmowska-Pietruszyńska A., Opieka zdrowotna dla osób z niepełnosprawnościami, [w:] Rehabilitacja - wsparcie - inkluzja: w kierunku polityki wobec niepetnosprawności, red. M. Anasza, J. Wojtyńska, H. Drachal, Warszawa 2016.

Kurowski K., Wolności i prawa człowieka i obywatela z perspektywy osób z niepełnosprawnościami, Biuro Rzecznika Praw Obywatelskich, Warszawa 2014.

Lach D.E., Kilka uwag o nowych instrumentach wsparcia dla osób niepełnosprawnych, „Praca i Zabezpieczenie Społeczne” 2018, nr 12.

Lach D.E., Zasada równego dostępu do świadczeń opieki zdrowotnej, Warszawa 2011.

Lipowicz I., Uwagi o polski systemie stanowienia prawa, „Państwo i Prawo” 2012, nr 7.

Lipowicz I., Dobro wspólne, „Ruch Prawniczy, Ekonomiczny i Socjologiczny” 2017, nr 3.

Paluszkiewicz M., [w:] Ustawa o rehabilitacji zawodowej i społecznej oraz zatrudnianiu osób niepełnosprawnych. Komentarz, red. M. Włodarczyk, WK/el. 2015.

Racjonalny ustawodawca, racjonalna administracja. Pamięci Eugeniusza Smoktunowicza, red. D.R. Kijowski, A. Miruć, A. Budnik, Białystok 2016.

Sikorski S., Konstytucyjne prawo do ochrony zdrowia oraz prawo do świadczeń opieki zdrowotnej finansowanych ze środków publicznych, [w:] E. Nojszewska, W. Malinowski, S. Sikorski, Komercyjne świadczenia usług publicznych przez szpitale publiczne, Warszawa 2017.

Surówka A., Miejsce konstytucyjnego prawa do ochrony zdrowia w systemie praw $i$ wolności człowieka i obywatela, „Przegląd Prawa Konstytucyjnego” 2012, nr 3.

Sygit B., Wąsik D., Prawo ochrony zdrowia, Warszawa 2016. 
Szklarski G., Konstytucyjne prawa socjalne, na tle zasady sprawiedliwości społecznej, „Przegląd Prawa Publicznego" 2014, nr 3.

Trzciński J., Wiącek M., Artykuł 68, [w:] Konstytucja Rzeczpospolitej Polskiej. Komentarz, t. 2, wyd. 2, red. L. Garlicki, M. Zubik, Warszawa 2016.

Urban K., Warmińska E., Nowe uprawnienia pacjentów niepetnosprawnych w systemie ochrony zdrowia w szczególności w zakresie rehabilitacji, LEX/el. 2018.

Ustawa o rehabilitacji zawodowej i społecznej oraz zatrudnianiu osób niepetnosprawnych. Komentarz, red. M. Włodarczyk, WK/el. 2015.

Ustawa o świadczeniach opieki zdrowotnej finansowanych ze środków publicznych. Komentarz, wyd. 3, red. A. Pietraszewska-Macheta, WKP/el. 2018. 